\title{
Fadrozole Hydrochloride
}

National Cancer Institute

\section{Source}

National Cancer Institute. Fadrozole Hydrochloride. NCI Thesaurus. Code C1044.

The hydrochloride salt of the nonsteroidal aromatase inhibitor fadrozole with potential antineoplastic activity. Fadrozole specifically inhibits aromatase, blocking the aromatization of androstenedione and testosterone into estrone and estradiol, respectively, the final step in estrogen biosynthesis; the reduction in estrogen levels may inhibit growth in estrogen-dependent cancers. Aromatase, a member of the cytochrome P-450 superfamily, is found in many tissues; overexpression has been linked to the development of preneoplastic and neoplastic changes in breast tissue. 